\title{
Akım Yönlendirilmiş Balon Uçlu Katater ile Oluşan İyatrojenik Pulmoner Arter Rüptürü: Nadir bir Vaka ve Literatür İncelemesi
}

\section{latrogenic Pulmonary Artery Rupture by Flow Directed Baloon-Tipped Catheter: A Rare Case and Review of The Literature}

\author{
Mustafa Serkan KARAKAS, MD'., Veysel TOSUN, MD¹., Murat BAYRAK, MD¹., Fatih KOC, MD'. \\ 1) Akdeniz University Medical Faculty, Department of Cardiology. Antalya, Turkey.
}

\section{ÖZET}

Akım yönlendirilmiş balon uçlu kataterler ile oluşan iyatrojenik pulmoner arter (PA) rüptürü sağ ve sol kalp kakaterizasyonu ve invaziv monitörizasyonun iyi bilinen ve nadir bir komplikasyonudur ve vakaların yaklaşık \%50'si ölümcüldür. Çoğu vaka rapor edilmemekte ve küçük yaralanmalara da muhtemelen olduğundan daha az tanı konulmaktadır. Swan-Ganz kataterizasyonundan sonra korkulan ve öldürücü olabilen PA yaralanmasının erken dönemde tanınması ve tedavi edilmesi önem taşımaktadır. Bu yazıda, sağ kalp kataterizasyonu sırasında ani başlangıçlı pulmoner alveolar hemoraji gelişen 64 yaşında pulmoner arteriyel hipertansiyonlu bayan hasta sunulmuştur. Hasta konservatif destek tedavisi uygulandı, kliniği stabil olan hasta sağlıklı olarak taburcu edildi.

Anahtar kelimeler: sağ kalp kataterizasyonu, pulmoner arter rüptürü, pulmoner arter yaralanması, Swan-Ganz katateri

\section{ABSTRACT}

latrogenic pulmonary artery injury caused by a flow directed balloon-tipped pulmonary artery catheter is a rare complication but remains fatal in almost $50 \%$ of cases. It is well-recognized complication of left and right heart catheterisation and invasive monitoring. Many cases are not reported and lesser injuries are probably underdiagnosed. Because of PA injury is a feared complication after Swan-Ganz catheterisation and can be fatal, quick recognition and treatment are essential. Herein, we reported a 64-year-old female of sudden onset pulmonary alveolar hemorrhage during right heart catheterisation in a pulmonary artery hypertension patient underwent catheterisation. The patent managed with conservative and supportive therapy and remained stable. She was discharged with complete healing.

Key Words: right heart catheterisation, pulmonary artery rupture, pulmonary artery injury, Swan-Ganz catheter

\section{Corresponding Author: Mustafa Serkan KARAKAS}

Adress: Department of Cardiology, Akdeniz University Medical Faculty, Dumlupinar Boulevard, Konyaalti, Antalya, Turkey.

E-mail: mserkan19@hotmail.com
Başvuru Tarihi/Received: 17-11-2015 Kabul Tarihi/Accepted: 08-12-2015 


\section{INTRODUCTION}

Pulmonary artery (PA) rupture is an uncommon iatrogenic complication of catheterisation during invasive cardiopulmonary monitoring. In the flow directed pulmonary artery Swan-Ganz catheterisation, pulmonary artery rupture is estimated to occur at a frequency of 0.05 to $0.2 \%(1,2)$. The mortality rate is $40-50 \%$ with this severe complication and can reach as high as $75 \%$ in anticoagulated patients (3). Pulmonary artery hypertension, elderly and female gender are other predisposing factors. In most cases, espicially during pulmonary artery wedge catheterisation, advanced cathater tip causes arterial wall damage and rupture (4). Due to having small bleeding areas death usually occurs secondary to asphyxia rather than hypovolemic shock.

In the case reports about PA rupture, it usually manifests as cardiogenic shock or sudden death, and is diagnosed postmortem $(1,5)$. In this case report, we described an iatrogenic rupture of a brunch of the right pulmonary middle lobar artery due to insertion of a flow directed balloon-tipped pulmonary artery catheter in a 64-year-old female and successful conventional management.

\section{CASE REPORT}

A 64-year-old female admitted to cardiology department with progressive dyspnea and shortness of breath, espicially in one month. The patient was diagnosed severe mitral regurgitation by echocardiography in an external center and referred to our hospital. Her previous medical treatment includes carvedilol, aspirin, spironolactone/hydrochlorothiazide and digoxin. Electrocardiography showed atrial fibrillation (72 beat/min). The 2-dimensional echocardiography showed severe tricuspid regurgitation, mild aortic regurgitation, moderate aortic stenosis, biatrial dilatation, general hypokinesia of left ventricular and left ventricular ejection fraction was $30 \%$ by simpson method. Systolic PA pressure was measured $76 \mathrm{mmHg}$ on echocardiography by bernoulli principle. Preoperative laboratory tests revealed no coagulation abnormalities or any other notable abnormalities, the INR (International Normalized Ratio) value was 1,03.
We planned invasive catheter to the patient because of echocardiography findings. She underwent to pulmonary artery catheterisation using a right femoral venous approach. Catheterisation was performed under radioscopy a guidance with a Swan-Ganz catheter. Systemic arterial blood pressure of the patient during right heart catheterisation was 143/87 $\mathrm{mmHg}$. The catheter was advanced and the balloon wedged into the left pulmonary artery. Pulmonary capillary wedge pressure was found $23 \mathrm{mmHg}$ after balloon-tipped PA catheter inflation in a branch of the right pulmonary artery. After balloon-tipped PA catheter deflation, the patient started coughing and soon afterward experienced massive hemoptysis with loss of at least 100 $\mathrm{ml}$ of fresh blood. General state of the patient worsened and the partial oxygen saturation of the patient reduced to $89 \%$. Patient's systemic arterial blood pressure value measured 180/100 $\mathrm{mmHg}$ and we quickly started intravenous nitrate infusion and intravenous furosemide (60 mg) with nasal oxygen therapy. We stopped the catheterisation, systemic arterial blood pressure measured $128 / 81 \mathrm{mmHg}$ after nitrate and furosemide therapy and the patient was transferred to the coronary intensive care unit (ICU). While the patient was in the ICU, a chest radiographyshowedcardiomegalyand pulmonary paranchimal opacity in the middle zone thought as pulmonary hemorrhage (Figure 1). Contrast computed tomography scan (CT) of the chest demonstrated about $3 \times 1,5 \mathrm{~cm}$ hematoma and pulmonary parenchymal hemorrhage in the right lung middle lobe periphery (Figüre 2). The patient was evaluated by thoracic surgeons, and she was recommended tranexamic acid. We started intravonous tranexamic acid $(500 \mathrm{mg}$, three times a day) for two days. The patient remained hemodinamically stable and she was free of hemoptysis. Catheterization was postponed to a later time. We did not give any antiplatelet or anticaogulant therapy to the patient for three days. The patient's hemoglobin levels were stable in the follow up. We followed a 'watch and wait' method. We started warfarin therapy for atrial fibrillation and she was discharged after 6 days. 


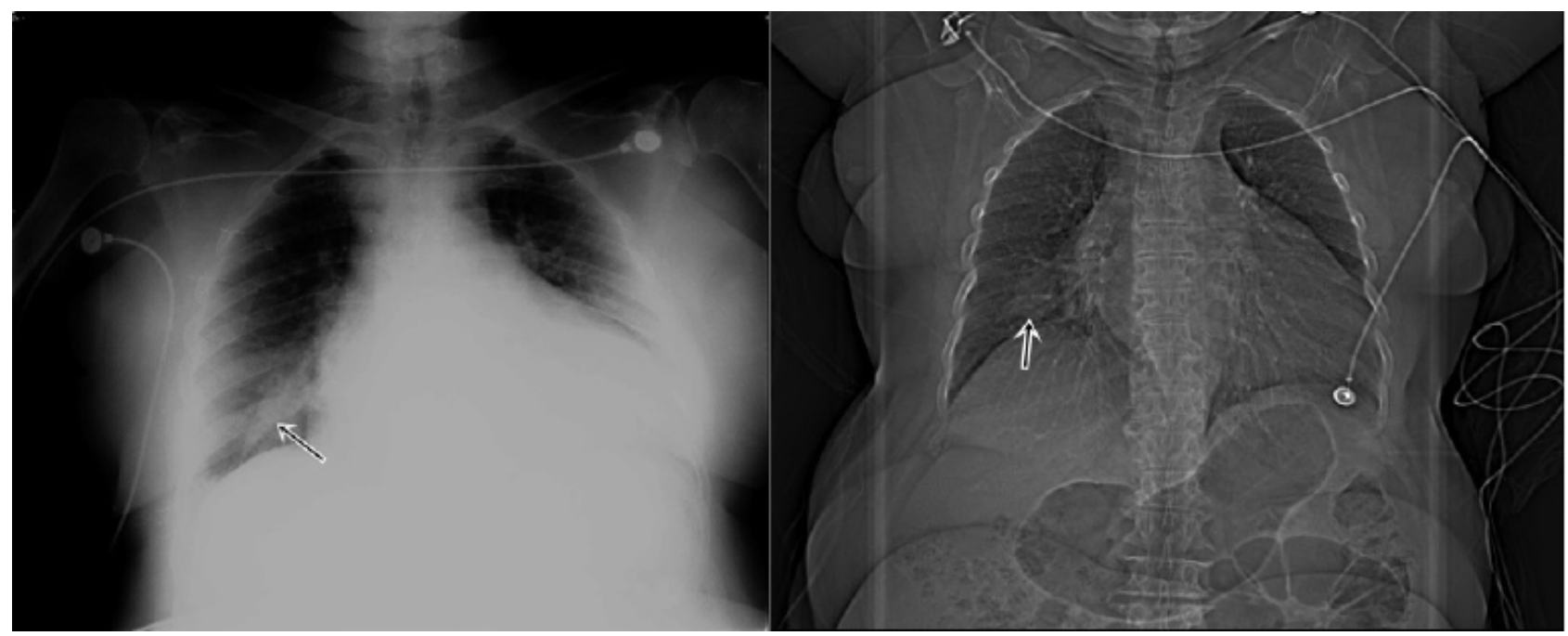

Figure 1: Chest radiography and computed tomography scan: cardiomegaly and pulmonary paranchimal opacity in the middle and lower lobe thought as pulmonary hemorrhage.

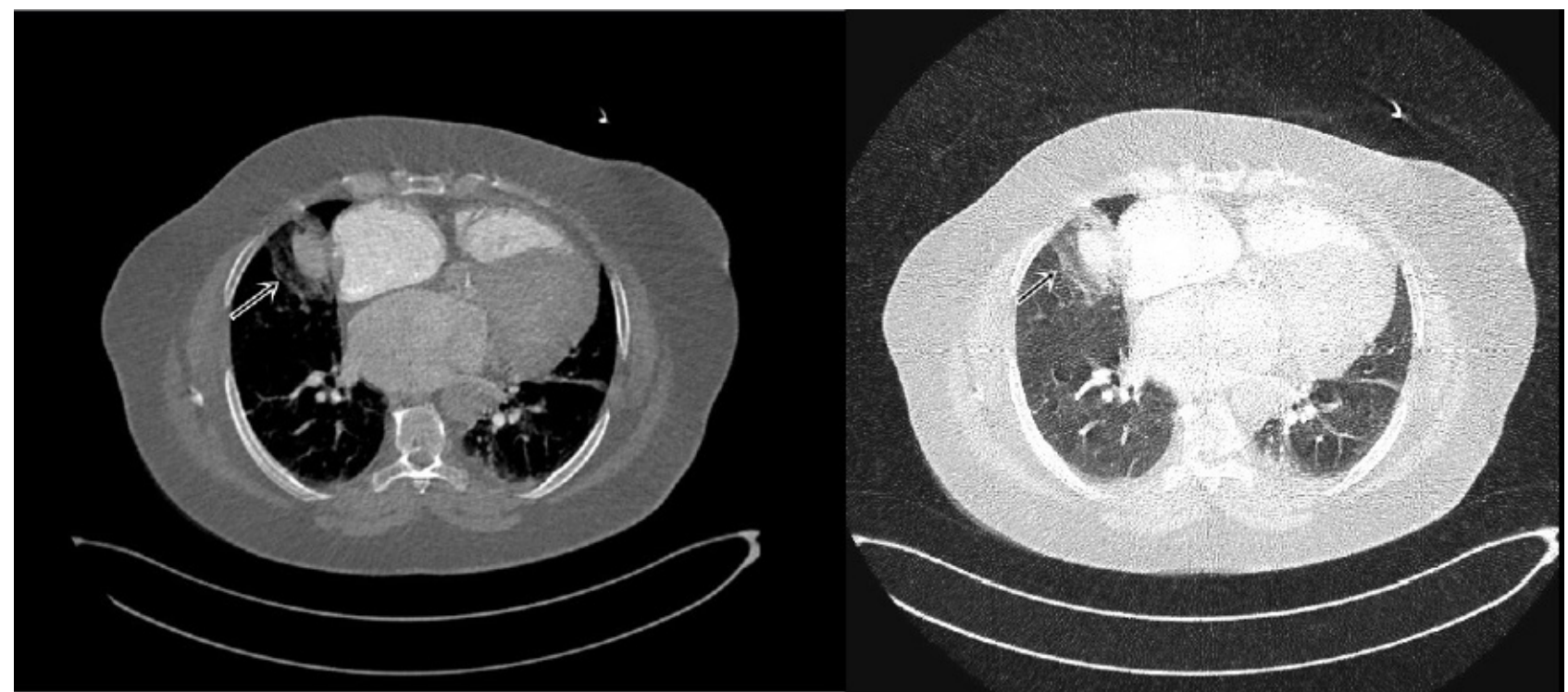

Figure 2: Contrast computed tomography scan (CT) of the chest, in the transverse section: about $3 \times 1,5 \mathrm{~cm}$ hematoma and pulmonary parenchymal hemorrhage (intra-pulmonary extravasation of contrast) in the right lung middle lobe periphery.

\section{DISCUSSION}

The flow directed balloon-tipped pulmonary artery catheter introduced by Swann and Ganz in 1970 has made possible the measurement of filling pressures in the heart and is extensively used in cardiac catheterisation laboratories and in intensive care units $(6,7)$. In PA catheterisation the balon-tipped catheter is floated through a central venous access, through the right atrium and right ventricle to the PA. When the balon is inflated in distal segment of PA, it measures pulmonary capillary wedge pressure.
Arterial puncture problems, postoperative pain and sensation deficit, air embolism, pneumothorax, dysrhythmias, heart block, pulmonary artery rupture, pulmonary infarction, pulmonary artery pseudoaneurysm, pulmoary venous thrombosis are complications of heart carhaterisations (8). The rupture of the PA is one of uncommon complication associated with a high mortality rate. It is a serious complication that has been observed with the use of SwanGanz catheters and has an estimated incidence of $0.031 \%$ and mortality rates of $70 \%$ in one 
study (9), incidence of $0.05 \%$ and mortality rates of $50 \%$ in another study (10).

Risk factors in PA injury or rupture with flow directed balloon-tipped PA catheter use include age $>60$ years, female gender, pulmonary hypertension, systemic anticoagulation, long-term steroid use and surgically induced hypothermia (11). Complications generally occur when excessive catheter manipulation, advancing the catheter tip too far peripherally and leaving the inflated balloon in the wedge position for long periods. Main symptoms are cough, hemoptysis, dyspnea and cardiac shock. In our case, cough and hemoptysis occured just after deflation of the catheter.

It is assumed that PA injuries often decrease completely with conservative treatment, but the natural progress of PA rupture is unclear. Some injuries recover without significant traces, but in some cases progress to pseudoaneurysm is seen. Nellaiyappan et al. reported one of the cases about PA injury with pseudoaneurysm formation after Swan-Ganz catheterization (12). It should be remembered that conservative management of the PA injury during catheterisation might have contributed to the higher mortality rate. In conclusion, PA injury is a feared complication after Swan-Ganz catheterization and can be fatal, so when this complication occurs, quick recognition and treatment are essential. Satler LF has developed a document for the recognition and management of PA injury (13). Also, Mullerworth et al. reported an algorithm about recognition and management of catheter induced PA rupture in seven patient undergoing cardiopulmonary bypass (4). Minor bleeding may cease spontanously, or may be controlled by bronchial intubation, correction of coagulation deficiences and positive end expiratory pressure. In patients who develop massive or recurrent hemoptysis after PA catheterisation, PA injury must be considered quickly and aggressive airway protection should be employed along with appropriate catheter based or surgical interventions (4). In our case, she presented with massive hemoptysis but after reducing blood pressure and furosemide injection her hemoptysis decreased, vital signs remained stable, oxygen saturation remained within normal limits.

In conclusion, PA rupture is a life-threatening and potentially lethal complication following PA catheterisation. PA catheters are routinely used in the cardiac catheterisation laboratories, intensive care units and especially for patients with decreased cardiac function and during cardiovascular surgical procedures. The flow directed balloon-tipped pulmonary artery catheters need to be operated with much caution, especially in patients who has risk factors.

Conflicts of interest: None declared.

\section{REFERENCES}

1. McDaniel DD, Stone JG, Faltas AN, et al. Catheter-induced pulmonary artery hemorrhage. Diagnosis and management in cardiac operations. J Thorac Cardiovasc Surg. 1981;82:1-4.

2. Urschel JD, Myerowitz PD. Catheter-induced pulmonary artery rupture in the setting of cardiopulmonary bypass. Ann Thorac Surg. 1993;56:585-589.

3. Bussieres JS. latrogenic pulmonary artery rupture. Curr Opin Anaesthesiol. 2007:20:48-52.

4. Mullerworth $\mathrm{MH}$, Angelopoulos $\mathrm{P}$, Couyant MA, et al.Recognition and management of catheter-induced pulmonary artery rupture. Ann Thorac Surg. 1998;66:1242-5.
5. Patel V, Mehta HJ, Sadikot RT. Pulmonary artery dissection and rupture in a patient with idiopathic pulmonary artery hypertension. Am J Respir Crit Care Med. 2014:189:e10-1.

6. Rajaram SS, Desai NK, Kalra A, et al. Pulmonary artery catheters for adult patients in intensive care. Cochrane Database Syst Rev. 2013;2:CD003408.

7. Swan HJ, Ganz W, Forrester J, et al. Catheterisation of the heart in man with use of a flow-directed balloontipped catheter. N Engl J Med. 1970;283:447-51.

8. Villaverde RV, Vanhaebost J, Grabherr S, Palmiere C. Pulmonary artery rupture during Swan-Ganz catheterisation: a case report. Leg Med (Tokyo). 2014;16:76-80. 
9. Kearney TJ, Shabot MM. Pulmonary artery rupture associated with the Swan-Ganz catheter. Chest. 1995; 108: 1349-1352.

10. Bossert T, Gummert JF, Bittner HB, et al. Swan-Ganz catheter-induced severe complications in cardiac surgery: Right ventricular perforation, knotting, and rupture of a pulmonary artery. J Card Surg. 2006; 21: 292-295

11. Poplausky M, Rozenblit G, Rundback JH, Crea G, Maddineni S, Leonardo R. Catheterinduced pulmonary artery pseudoaneurysm formation: Three case reports and a review of the literature. Chest. 2001; 120: 2105-2111.

12. Nellaiyappan M, Omar HR, Justiz R, Sprenker C, Camporesi EM, Mangar D. Pulmonary artery pseudoaneurysm after Swan-Ganz catheterization: a case presentation and review of literature. Eur Heart J Acute Cardiovasc Care. 2014; 3:281-8.

13. Satler LF. latrogenic pulmonary artery rupture: the realities of management. Catheter Cardiovasc Interv. 2013; 1;81:60-1. 